\title{
Mid-Holocene vegetation change in the Troad (W Anatolia): man-made or natural?
}

\author{
Simone Riehl · Elena Marinova
}

Received: 15 September 2006/Accepted: 11 December 2006/Published online: 4 July 2007

(C) Springer-Verlag 2007

\begin{abstract}
New wood charcoal data from two archaeological sites in western Anatolia (Kumtepe and Troy/ Çanakkale province) enabled a review of earlier reconstruction of the mid-Holocene vegetation and land use patterns in the region. Multi-proxy data from archaeology, zooarchaeology and climatology are combined to evaluate the relationship of climate-induced and man-made environmental change for a period spanning the Late Neolithic to the Early Bronze Age (ca. 5000-2450 cal в.с.). During the first settlement period (Kumtepe A: ca. 5000-4600 cal B.C.) lush vegetation with high proportions of deciduous oak and pine prevailed, enabling the intense use of natural resources by the late Neolithic population, which use might be reflected in the first few representatives of maquis vegetation. A settlement hiatus at the site between roughly 4600 and $3500 \mathrm{cal}$ B.c. includes a cooling event in the Aegean and may have supported persistence and/or development of open vegetation units. However, the hiatus may have ended with a period of regeneration of the vegetation. From Kumtepe B2 (ca. 3300 cal в.c.) onward, human impact becomes clearly visible, although the main
\end{abstract}

Communicated by G. Willcox.

\section{S. Riehl}

Institute of Early Prehistory and Quaternary Ecology,

Tübingen University, Burgsteige 11, 72070 Tübingen, Germany

S. Riehl $(\bowtie)$

Center for Climatic Research, University of Wisconsin,

1225 W. Dayton St., Madison, WI 53706, USA

e-mail: sriehl@wisc.edu

\section{E. Marinova}

Department of Botany, Sofia University "St. Kliment Ohridski", 8 Dragan Tzankov, 1164 Sofia, Bulgaria

e-mail: elena_marinova@gmx.de woodland taxa continue to prevail. In all, environmental and economic dynamics between 5000 and 2300 cal B.c. in the Troad can be characterised as at least two alternating developmental sequences of climate-induced vegetation change and reinforcement of woodland degradation by human activity.

Keywords Climate change - Deforestation - Neolithic · Chalcolithic A Archaeobotany - Wood charcoal

\section{Introduction}

The Troad is crucial to Mediterranean prehistory through its importance in cultural and economic relations between the Black Sea region, the Aegean and the prehistoric settlement centres of Inner Anatolia (Korfmann 1991-2006, Fig. 1). Although environmental archaeologists contributed intensively to the understanding of landscape development in western Anatolia, vegetation history in this area is still far from being well-investigated, as neither representative, well-dated palynological results are available, nor are anthracological results available for the wider region. Vegetation reconstruction models are therefore mainly based on palaeoclimate proxies from more distant regions (Roberts et al. 2004). Particularly in a region where climate, marine and anthropogenic changes may have had an impact on vegetation during the Holocene, detailed reconstruction is needed to assess patterns of environmental change.

The crop and wild plant assemblages at Troy and Kumtepe (a small tell site $5 \mathrm{~km}$ north-northwest of Troy) analysed by Riehl (1999) led to the hypothesis of an economic change between the Late Neolithic Kumtepe A and Chalcolithic Kumtepe B settlements. Plant production patterns at Early Bronze Age Troy (Troy I and II) are more similar to 


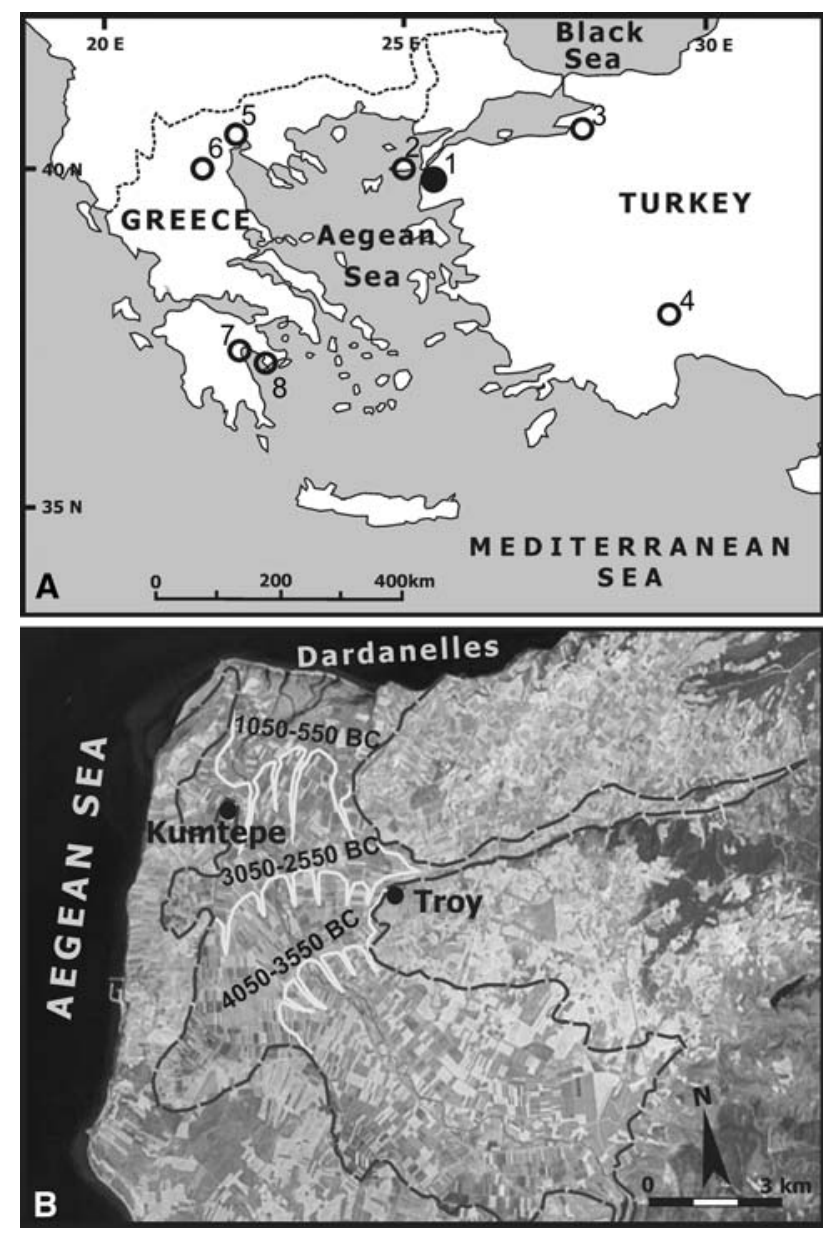

Fig. 1 a Geographical position of the study area and other sites with archaeobotanical results referred to in the text: 1 Kumtepe and Troy; 2 Yenibademli Höyük; 3 Ilıpınar; 4 Kuruçay; 5 Kastanas; 6 Servia; 7 Lerna; 8 Franchthi Cave. b Palaeogeographical reconstruction: dashed black line-land over $40 \mathrm{~m}$; solid white line-former delta (delta propagation and coastline changes for various time periods according to Kayan et al. 2003). Note that the coastlines of 40503550 в.с. and $3050-2550$ в.с. correspond to the second half of the hiatus at Kumtepe and to Troy I/II, respectively

those at the earlier Kumtepe B than to those from any of the later periods at Troy. Considering the occupation hiatus between both Kumtepe periods and their differing pottery assemblages, the change in subsistence patterns was most probably connected with populations of different origin in both settlements. Based on carpological, zooarchaeological and geomorphological data, reduction of woodland was inferred for the Early Bronze Age around Troy.

Meanwhile, our understanding of the palaeoclimatic development has improved through recent research (e.g. Rohling et al. 2002; Mayewski et al. 2004), suggesting a global Holocene cooling event during the settlement hiatus at Kumtepe.

New charcoal data from the Troad provide important information on the use of woodland (and more generally on the surrounding vegetation) and enable the re-evaluation of earlier interpretations of environmental change and the economic history of the sites. Interactions between environmental and cultural development are complex and it is still often impossible to resolve their components. However the multidisciplinary approach of integrating the archaeological, faunal and botanical evidence may help in clarifying questions on the interdependence of climate induced environmental change, human adaptation processes and anthropogenic transformation of the environment during the later phases of the Holocene.

In this paper we evaluate archaeological and bioarchaeological data for the reconstruction of the environmental dynamics in the Troad from the Late Neolithic to the Early Bronze Age, with the main purpose of distinguishing periods of prevailing climate change from periods of predominantly human impact.

All radiocarbon data are given in calibrated years в.c. Calibration was performed using http://www.calpalonline.de (Weninger et al. 2005).

\section{Archaeological and environmental setting}

Archaeology and settlement development

The western Anatolian site of Kumtepe, a flat mound with dimensions of ca. $80 \times 100 \mathrm{~m}^{2}$, is situated about $2.5 \mathrm{~km}$ from the Dardanelles and $2 \mathrm{~km}$ from the Aegean Sea (Fig. 1). It was excavated in 1934 by Sperling, continued by Korfmann and his team between 1993 and 1997 (Sperling 1976; Korfmann et al. 1995, 1996). The upper city of Troy, a large hill, ca. $200 \times 150 \mathrm{~m}^{2}$ in dimension, is situated about $5 \mathrm{~km}$ to the southeast of Kumtepe, but was separated from the latter by the sea until at least the Middle Bronze Age (Figs. 1b, 8) (Kayan et al. 2003). Additionally, the Late Bronze Age site of Troy includes a lower city extending about $200,000 \mathrm{~m}^{2}$ around the tell (Schliemann 1881, 1884; Dörpfeld 1902; Blegen 1950; Korfmann 19912006).

Kumtepe $\mathrm{A}$ is the earliest settlement in the Troad and was settled during the Late Neolithic (according to Aegean terminology). It shows typological similarities to some of the Aegean insular assemblages (Gabriel 2000). Three other locations in the Troad with similarly early material, but starting slightly later, are known (Beşik-Sivritepe and the surface finds of Çıplak Köyü and Alacalıgöl, Gabriel et al. 2004; Fig. 8).

The Kumtepe A layers are followed by a settlement hiatus lasting for several hundred years (Figs. 3, 9), which is succeeded by the Chalcolithic layers of Kumtepe B, subdivided into three phases (Kumtepe B1 starting roughly around 3500 cal B.C., Kumtepe B2 and Kumtepe B3 ending 
around $3000 \mathrm{cal}$ в.с. at the latest). Radiocarbon dating of the Kumtepe B layers has so far only been performed on Kumtepe B2 material. The Chalcolithic pottery of Kumtepe shows only slight similarities to the Anatolian inland inventories, but has parallels on the Anatolian west coast and in eastern Thrace.

Kumtepe C, which was neither extensively excavated nor sampled for bioarchaeological remains, is simultaneous with Troy I, starting around 3000 cal B.c. (Troy I: 29202600 cal в.c., Troy II: $2600-2450$ cal в.c. (EBA IIb) according to Korfmann and Kromer 1993). Pottery from both sites is identical in material and form, and compares well to that of the Cyclades.

The archaeological remains suggest that the Troad had, at least until the end of the Early Bronze Age, a close cultural and economic relationship with the Aegean region.

Modern climate and actual and potential vegetation

Today, both sites are within the typical eastern Mediterranean climate zone, with hot, arid summers and moderately cool and moist winters. Also characteristic is a strong annual variability in mean annual precipitation (for Çanakkale a range of 520-980 mm was registered between 1961 and 1972; Alex and Burry 1982).

The Troad, predominantly part of the Mediterranean phytogeographic region (East Mediterranean province or Eu-Mediterranean woodland type, according to Zohary 1973), shows many affinities with the east Aegean islands and even with the Greek mainland (Davis 1965-1988, vol 1, 21).

Characteristic of the Mediterranean province is evergreen sclerophyllous vegetation (dominated by Quercus coccifera), but geophytes, therophytes and suffrutescent chamaephytes are also numerous. Generally maquis vegetation dominates below $1,000 / 1,200 \mathrm{~m}$, while above $1,000 /$ $1,200 \mathrm{~m}$ in the Mediterranean region conifers largely prevail.

As early as 1879 Virchow mentioned the considerable woodland degradation resulting from economic overuse (wood cutting and grazing). According to this author only in the mountain areas was the vegetation richer. Valonea oak (Quercus aegilops, according to Virchow) seems to have been the most common deciduous oak tree near fields during that time, and was well developed mainly along river valleys (Fig. 2).

However in the 20th century in the surroundings of Kumtepe and Troy, an agricultural landscape has almost totally replaced the natural vegetation, with most of the area today being irrigated or used for pasture (compare Figs. 1 and 2). A description of the present-day vegetation around the sites is provided by Riehl (1999).

Potentially xerotherm oak [Quercus cerris L., Q. frainetto Ten., $Q$. pubescens Willd., $Q$. robur L., $Q$. infectoria

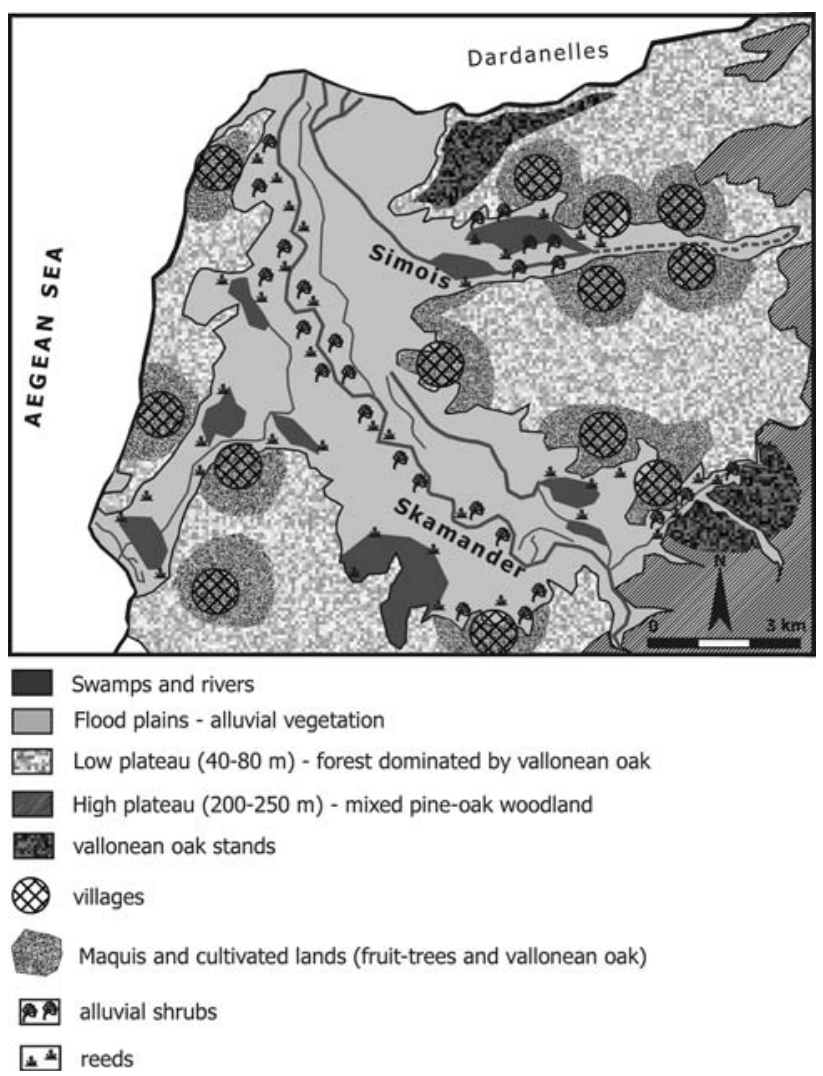

Fig. 2 Landscape of the Troad during the second half of the 19th century, according to Virchow (1879)

Olivier, $Q$. trojana Webb (syn: $Q$. macedonica DC), $Q$. ithaburensis ssp. macrolepis (Kotschy) Hedge and Yalt (syn: $Q$. aegilops, $Q$. vallonea, $Q$. macrolepis, $Q$. pyrami)] and Turkish pine forests [Pinus brutia Ten. (syn: P. pityusa Stev.)] could have developed in the Troad. The two latter oak species, Valonea oak ( $Q$. ithaburensis ssp. macrolepis) and Macedonian oak (Quercus trojana) are still relatively common in the area. Both species are tall trees (15-20 m) that are well adapted to warm continental climatic conditions and are resistant to summer droughts and cold winters with frost. Macedonian oak has a relatively wide ecological range, growing in semi-shade (light woodland) or open plant associations. The other potential species in the area under consideration are Turkish (or Bitter) oak (Q. cerris) and Downy oak (Q. pubescens), which may have grown on the high plateau (above $200 \mathrm{~m}$ a.s.l.), forming xerothermophilous forest. Common oak ( $Q$. robur) could have been an element of the alluvial forests in the area.

Turkish pine (Pinus brutia) is one of the most important forest trees in the north eastern Mediterranean area. Considering its ecological requirements, it should potentially form forests in the coastal area and on the high plateau of the Troad, as it is widespread from almost sea level to 1,000-1,200 m (Browicz 1994). 
In the Scamander River valley, alluvial and swamp vegetation could potentially be present (as e.g. Fraxinus angustifolia s. 1., Ulmus minor and partly Alnus glutinosa, Bohn et al. 2003). Other frequent taxa in this type of vegetation are Quercus spp., with lianas such as Smilax excelsa and Periploca graeca in combination with alluvial willow and poplar forests (Salix alba, Populus alba, Populus nigra). In the eastern Mediterranean brackish zone near the river delta shrubs with Tamarix spp., Vitex agnuscastus, and Juncus spp. have developed.

Palaeoclimate and environmental proxy data

Although work is in progress by the second author, no palynological data for the Troad is available so far.

Bottema and van Zeist (1980) inferred an overall increase in humidity in West Asia after the Pleniglacial period until at least 4000 cal B.C., with regional differences, such as a later increase of humidity in south eastern Turkey, deduced from woodland expansion (oak forests) at Lake Van around 8500 cal B.C.. Increased available moisture from the early Holocene until around 5000 cal B.c. is confirmed by many recent proxy records for a number of areas, such as the eastern Mediterranean Sea (deep-sea pollen cores; Rossignol-Strick 1999) and Central Anatolia (pollen and geochemical cores from Lake Eski Acigöl, Roberts et al. 2001).

For the periods after 5000 cal B.c. the interpretation of palynological data becomes more complex because of increasing human impact on the environment, which is, at least for the vegetation cover, difficult to distinguish from climatic increase in aridity. These may, in fact, be interrelated.

Van Zeist and Bottema (1991) considered much of the forest and woodland they inferred from palynological results in the wider eastern Mediterranean area at around 2000 cal B.C. to have been relatively undisturbed. Maquis seems to have been much more restricted in the past, and a deciduous oak forest probably dominated this zone at least until the Early and Middle Bronze Ages, which correlates with biomisation models for this region (Roberts et al. 2004). In the case of the Yenişehir area near Ilipinar, a decline in deciduous forest already started around 5000 cal B.C., but the decrease in deciduous oak pollen intensifies particularly during the Late Chalcolithic to Early Bronze Age occupation in the area (Bottema et al. 2001).

In the absence of Holocene climate proxy data for the Troad itself, the evidence from other regions would suggest humid conditions prevailed at the Late Neolithic settlement of Kumtepe A (5000-4600 cal B.C.), while the Chalcolithic Kumtepe B (3500-3000 cal B.C.) and Early Bronze Age Troy (3000-2350 cal B.C.) settlements may have experienced a more arid climate. This would be at least in rough agreement with sea level changes documented for the coastal area around the Troad. Kayan (1995) found a rising sea level during the early Holocene until around 4000 cal B.C., when it reached the modern sea level. Around $3200 \mathrm{cal}$ B.C. the sea level started to decrease again.

Archaeobotanical studies at Kumtepe and Troy based on seeds imply an expanding openness of the vegetation from at least the Early Bronze Age onward. The assemblages are characterised by an increase in maquis and garrigue elements, although definite maquis-type taxa (Sarcopoterium spinosum, Cistus spp.) are sparsely represented at Early Bronze Age Troy (Riehl 1999).

Changes in proportions of the domesticated fauna at Kumtepe were environmentally interpreted to indicate an open landscape during the Kumtepe A period, a developed oak forest cover during the Kumtepe B period and a reopening of the vegetation during Kumtepe $\mathrm{C}$ period. At least the interpretation for the Kumtepe A vegetation is in contrast to that of the climate development. For the animal husbandry at Troy I/II, besides environmental adaptation, socio-economic factors are also discussed as determinants (Uerpmann 2003).

In 1998 a buried soil, which had developed during the settlement hiatus at Kumtepe, was discovered (Fig. 3). Its characteristics (intensive dark pigmentation with a diffuse lower boundary) are typical of terrestrial ecosystems rich in subterranean biomass like open vegetation. So far this has provided the only evidence for the local vegetation cover during the settlement hiatus (Pustovoytov 1999).

\section{Materials and methods}

In view of the methodological problems of many singleproxy based approaches (multiple paths of interpretation) in elaborating climate and human-forced environmental change, we decided to make use of the different data sources from one location. This would enable better identification of indicators relevant to environmental development due to either climate change or human impact. We aimed to test different hypotheses available from previous studies through consideration of multiple lines of evidence from charcoal and seed remains, zooarchaeological evidence and available palaeoclimate data.

This involved the following questions:

1. Can we recognize the presence of higher moisture levels before around 5000-4000 cal B.C. as deduced from pollen and other palaeoclimate proxies in our data? What would these results mean for the Late Neolithic settlement period at Kumtepe A and the settlement hiatus, which both fall partially into this time period? 
Fig. 3 Profile of Kumtepe A and $\mathrm{B}$ layers and the layer of soil formation (hiatus) with ${ }^{14} \mathrm{C}$ data: radiocarbon dates $*$ from wood charcoal (Gabriel 2000),

** from humic acids

(IGAS-1751). Note that there is no alluvial forest represented in Kumtepe A samples

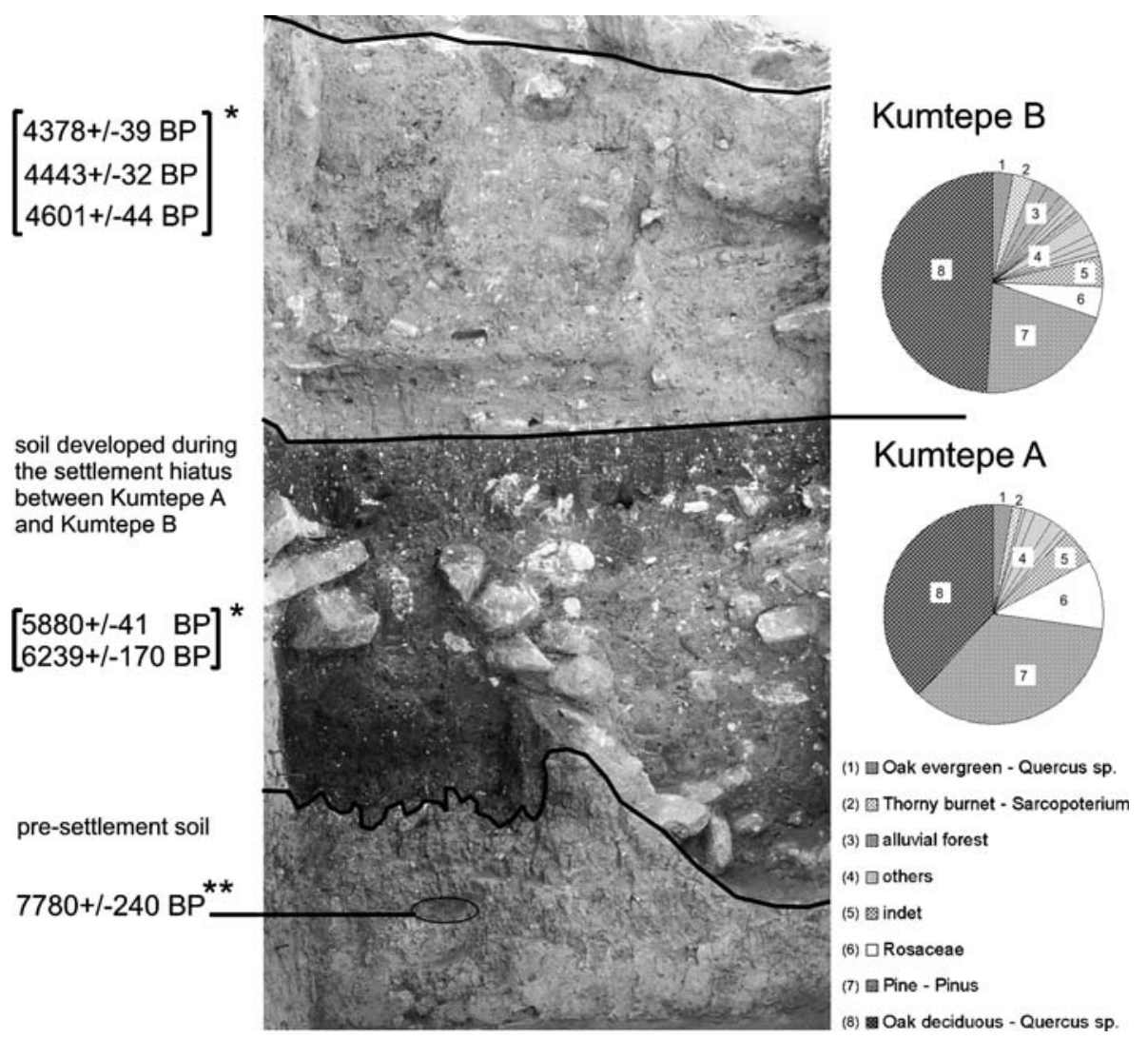

2. Are our data able to specify the regional starting point of increased aridity as either an early (5000 cal в.c.) or a late (3200 cal в.с.) date, as indicated in global and regional palaeoclimate proxies? How would this affect the settlement development during Chalcolithic Kumtepe B and Early Bronze Age Troy?

3. How far do our data contribute to the palynological dispute about the beginning of oak woodland degradation in the area, and how do these new data correlate with earlier bioarchaeological records from the area?

The different types of data reflect different types of information. Seed data mainly give information on the economic system and subsistence, but only to certain extent on the non-agricultural vegetation, and even less on ancient woodland vegetation. Wood charcoal provides a firm insight into the latter aspect apart from woodland use. The zooarchaeological data which was used for environmental reconstruction needed a revision, because depending on the quantification measurement used (WISP - weight of identified specimens, or NISP-number of identified specimens), different environmental patterns would emerge.

However palaeoclimatological and pollen data can only be used as a general trend line, as the regional patterns may diverge from these.

The lack of direct palaeoclimate proxies may be partially compensated by considering palaeoclimate models. A macrophysical climate model (MCM) developed by Bryson is available at the Center for Climatic Research, University of Wisconsin, Madison, WI, USA (Bryson 1992, 2005). The initial input is orbital forcing, in this case solar radiation based on Milankovitch cycles (Bryson 1988). In contrast to most GCMs (General Circulation Models), the MCM receives its higher spatial resolution from a volcanic index (Bryson and Bryson 1997, 1998), based on the assumption that aerosols are relevant for incoming radiation thus determining the albedo.

However, we only considered the occasional use of a precipitation model under MCM, because climate models still lack sufficiently comprehensive verification from palaeoclimate data for their systematic application to archaeological questions.

The integration of the different types of data remains a difficult task compounded in addition by methodological problems, and so far can only be done by careful comparison.

Subsistence patterns may be environmentally determined to a certain degree, and were considered mainly under this assumption. For the evaluation of economic systems and subsistence strategies, sites located in Greece had to be included because few data are available for western Anatolia [Ilıpınar VB (Cappers 2001), Kuruçay 6A (Nesbitt 1996), Fig. 1]. In Greece, Late Neolithic seed data 
is available from Servia (southwest Macedonia, Hubbard 1979) and the Franchthi Cave (Argolid peninsula, Hansen and Renfrew 1978; Hansen 1991). Sufficient archaeobotanical data for Early Bronze Age sites is, apart from Troy, also available from Yenibademli Höyük (Oybak-Dönmez 2005), Kastanas (Kroll 1983) and Lerna (Hopf 1961).

The results on the use of woodland and vegetation development in the Troad are primarily based on the analysis of more than 1,800 charcoal fragments from 44 samples deriving from the periods Kumtepe A, Kumtepe B and Early Bronze Age Troy. They are also based on approximately 15,000 seed remains from 38 Kumtepe A and B samples, and around 11,700 remains from 23 Early Bronze Age samples from Troy I and II layers. These samples also contain the information on subsistence strategies and agricultural patterns (Riehl 1999).

Sampling strategy for flotation was a combination of systematic and judgmental sampling. Although the number of samples is low for Kumtepe A, the find density and number of taxa are comparatively high in the seed and charcoal remains (Table 1). Therefore, we assume we have retrieved assemblages that are fairly representative of the different periods and sites.

All remains originated from the flotation of sediments mainly from pits, floors and occupational debris. Such long-term accumulations (in contrast to construction wood from burnt layers) provide a more representative sample of the vegetation over a longer time span (cf. Heinz and Thiébault 1998; Asouti and Austin 2005). Three samples of construction wood consisting of pine trees and another containing only Celtis were omitted from the final analysis. Additional samples are derived from a profile (Fig. 3) that covers the whole sequence of the Kumtepe A and B layers, separated by the layer of soil formation mentioned above representing the settlement hiatus at the site.

The laboratory study was carried out on freshly fractured charcoal $(>2 \mathrm{~mm})$ in three anatomical planes (transverse, tangential and radial) using a reflected light microscope. Identification literature (Schweingruber 1990) and a reference collection of modern wood samples from North-western Turkey were used. The material was both counted and weighed.

The charcoal data are given as absolute numbers and percentage counts in Tables 1 and 2 and are plotted in Fig. 6. To estimate the relative importance of the different wood taxa, their ubiquity was also calculated.

The analytical methods applied to the seed remains are described in Riehl (1999).

Reconstruction of the vegetation in the surroundings of Kumtepe and Troy during different periods integrates data from the charcoal remains and the knowledge of prehistoric topography and land use, as available from

Table 1 Details of the botanical samples from Kumtepe A (Late Neolithic), Kumtepe B (Chalcolithic) and Troy I/II (Early Bronze Age) (* charcoal samples)

\begin{tabular}{|c|c|c|c|c|c|c|c|}
\hline & \multicolumn{7}{|l|}{ Period } \\
\hline & Kumtepe A & $\begin{array}{l}\text { Kumtepe B (not } \\
\text { specified; profile) }\end{array}$ & $\begin{array}{l}\text { Kumtepe B } \\
\text { (all phases) }\end{array}$ & Kumtepe B1 & Kumtepe B2 & Kumtepe B3 & Troy I/II \\
\hline No. of samples & $9 / 6^{*}$ & $11 / 6^{*}$ & $28 / 20^{*}$ & $5 / 4 *$ & $6 / 5^{*}$ & $6 / 5^{*}$ & $25 / 18^{*}$ \\
\hline Total volume (1) & $>143$ & 245 & $>468$ & Unknown & Unknown & 223 & $>548$ \\
\hline Seed density $\left(1^{-1}\right)$ & 13 & 13 & - & - & - & 35 & 21 \\
\hline No. seed taxa & 55 & 78 & 141 & 50 & 60 & 103 & 130 \\
\hline No. of identified charcoal & 340 & 256 & 876 & 56 & 211 & 344 & 609 \\
\hline Weight of idenitified charcoal $[\mathrm{g}]$ & 1.81 & 9.13 & 37.18 & 3.15 & 17.9 & 7 & 29.24 \\
\hline No. of charcoal taxa & 14 & 19 & 23 & 7 & 12 & 18 & 21 \\
\hline \multicolumn{8}{|l|}{ Wood charcoal composition in $\%$} \\
\hline Woodland & 64 & 71 & 63 & 79 & 47 & 62 & 71 \\
\hline Open vegetation & 21 & 15 & 22 & 11 & 42 & 18 & 15 \\
\hline Alluvial and estuarine area vegeation & 3 & 9 & 9 & - & 6 & 13 & 9 \\
\hline Others (incl. indets.) & 12 & 5 & 6 & 10 & 5 & 7 & 5 \\
\hline \multicolumn{8}{|l|}{ Seed remain composition in $\%$} \\
\hline Crops & 91 & 69 & 63 & 60 & 72 & 60 & 36 \\
\hline Weeds & 3 & 12 & 12 & 22 & 18 & 10 & 3 \\
\hline Open vegetation (incl. maquis etc.) & 5 & 18 & 24 & 18 & 9 & 29 & 55 \\
\hline Woodland & 0 & 0 & 0 & 0 & 0 & 0 & 3 \\
\hline Habitats near water sources & 1 & 1 & 1 & 0 & 1 & 1 & 3 \\
\hline
\end{tabular}

*Charcoal samples 
geomorphological, zooarchaeological and carpological research (Figs. 7, 8, 9).

Considering both the archaeobotanical findings and the potential natural habitats in the area, at least five different types of vegetation can be assumed to have been present in prehistory:

1. Woodland

2. Shrubs, maquis and open vegetation

3. Alluvial vegetation

4. Reeds and swamps

5. Halophytic vegetation.

The localisation of the different vegetation types is mainly based on geomorphological units, e.g. oak-pine woodland on the low and high plateau, shrub and maquis on the plateaux and on the slopes, alluvial vegetation, reeds and swamps in the river valley and halophytic vegetation near the coast. We assume halophytic vegetation and swamps would have colonised the new areas created by the falling sea level and/or deltaic progradation. Basic geomorphological and detailed geoarchaeological information on the Troad is taken from Kraft et al. (1982), Kayan (1999), and Kayan et al. (2003).

The term woodland in our reconstruction describes forests consisting of deciduous oak distributed in the area, but also forests dominated by Pinus brutia. These forests are considered to have grown both on the high and low plateaux. On the slopes exposed to winds from the sea, dominance of P. brutia is assumed.

Another type of woodland vegetation not included in the group described above is summarised under the term "alluvial vegetation". These are mainly riverine forests represented in the wood charcoal record by various taxa (Salix spp., Populus spp. but also shrubs with Tamarix sp. etc.) (Table 2). Some deciduous oak species (Quercus robur, Q. ithaburensis ssp. macrolepis) could originate both from xerothermic oak forests situated on the slopes and plateau surrounding the Scamander delta, or from the riverine forests, which could have had developed in the delta. Together with these latter forests, some scrubby forms of Tamarix, Vitex agnus-castus, Populus and Salix could have developed in the alluvial zone. Such scrub combined with Juncus sp. could have grown close to the brackish water zone of the estuarine area. The latter genus was strongly represented in the seed remains. Also in this area, reeds, swamps and halophytic vegetation are to be expected. The remains of the reeds represented by Phragmites are recorded both in the wood charcoal and seed remains.

Evidence for shrubs, maquis and open vegetation appears in both wood charcoal and seed remains (Tables 1,2). In the present reconstruction we expect this vegetation to occur on stony patches and slopes as documented by Kayan et al. (2003) and on the sand dunes of the coastal area.

\section{Results}

Late Neolithic [ca. (5500) 5000-4600 cal в.c.]

Lentil (Lens culinaris) and bitter vetch (Vicia ervilia) dominate crop and food plant remains. Cereals appear in comparatively lower proportions in the Kumtepe A occupation. However, the ubiquity pattern suggests a more balanced mixed economy, primarily containing figs and lentils, but also with a relatively high frequency of einkorn (Triticum monococcum), six-row barley (Hordeum vulgare) and emmer (Triticum dicoccum) remains (Fig. 4). Flax (Linum usitatissimum) was also cultivated and figs and grapes were collected, most probably from the wild.

Taken as a whole (and not specifically for each of the Kumtepe B phases), species diversity amongst the wild plant taxa of the Kumtepe A samples is considerably lower than in the Kumtepe B samples (Table 1). This relates to the relatively low sample numbers from Kumtepe A. Considering that presence or absence of taxa may indeed reflect sampling biases, it was decided to focus on the changes of frequencies in taxa that are present throughout the Kumtepe A and Kumtepe B sequence (Fig. 5). Within this selected group the most frequent wild taxa during Kumtepe A are rush (Juncus sp.) and grasses, either representing cereal weeds or part of the natural vegetation. A significant taxon, in terms of the openness of the vegetation, is rock rose (Cistus sp.), a representative of open shrubby habitats. Its seeds are present only in Kumtepe A samples.

The wood remains from Kumtepe A are predominantly of the large woodland species deciduous oak and pine, with deciduous oak exceeding pine slightly in the number of charcoal pieces and greatly in charcoal weight. Evergreen oak is also present, but only with a few records (Table 2, Figs. 6, 7).

As indicated above, species diversity is lowest in the Kumtepe A remains due to fewer samples from this period. However, this may not hold for the sparseness in charcoal taxa representing alluvial riverine forests, which are present as much fewer species than other vegetation units. In view of the palaeogeographic situation, these units ought to have been further away from Kumtepe (Figs. 6, 8).

Chalcolithic (ca. 3500-3000 cal B.c.)

The crop assemblage is dominated by emmer and einkorn remains, while barley contributes a small amount to the data set. Figs and grapes, occur in relatively high proportions during Kumtepe B (Fig. 4). No significant differences between the crop production patterns of the different phases are visible, except the appearance and increase in frequency of bitter vetch from Kumtepe B2 onward. 


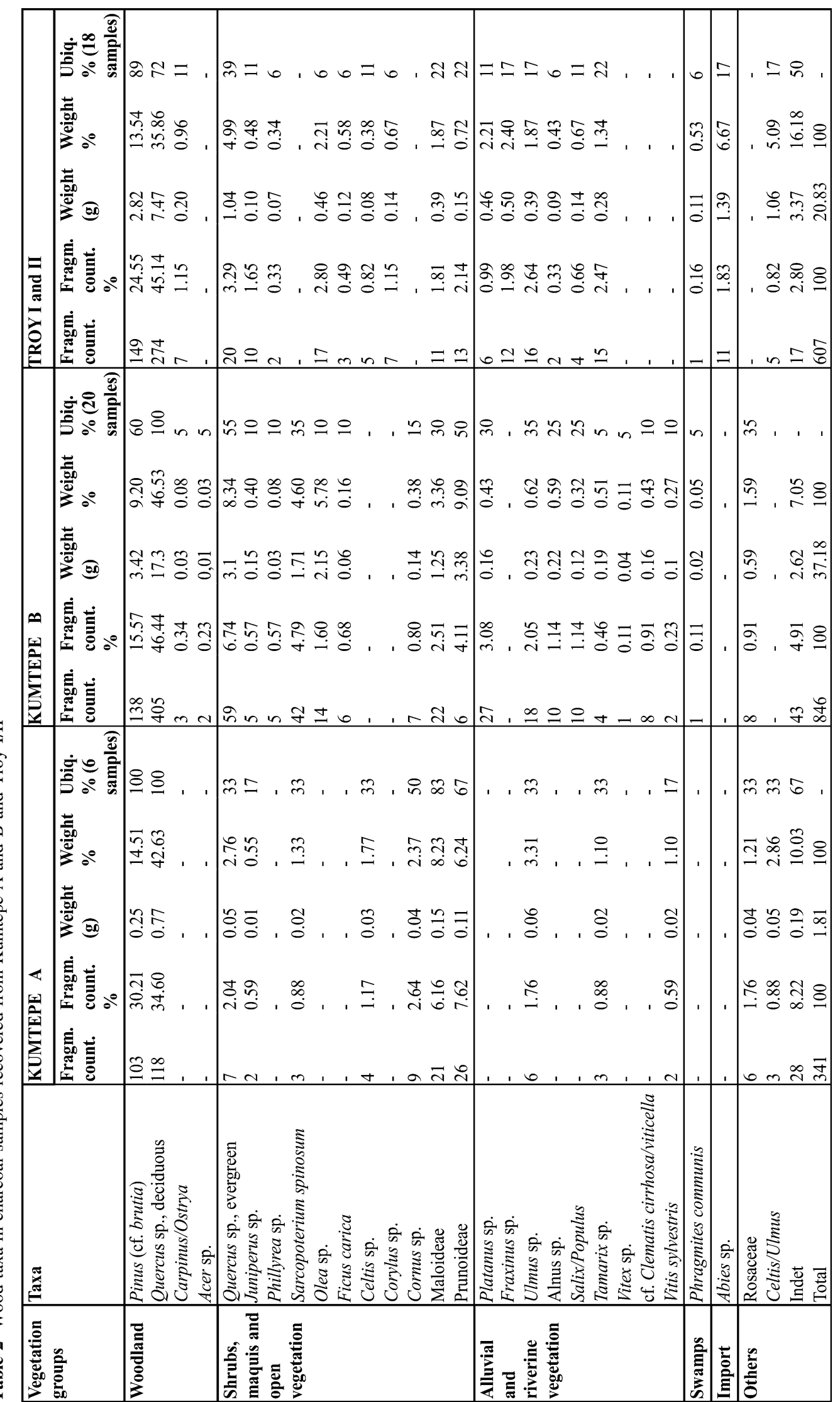




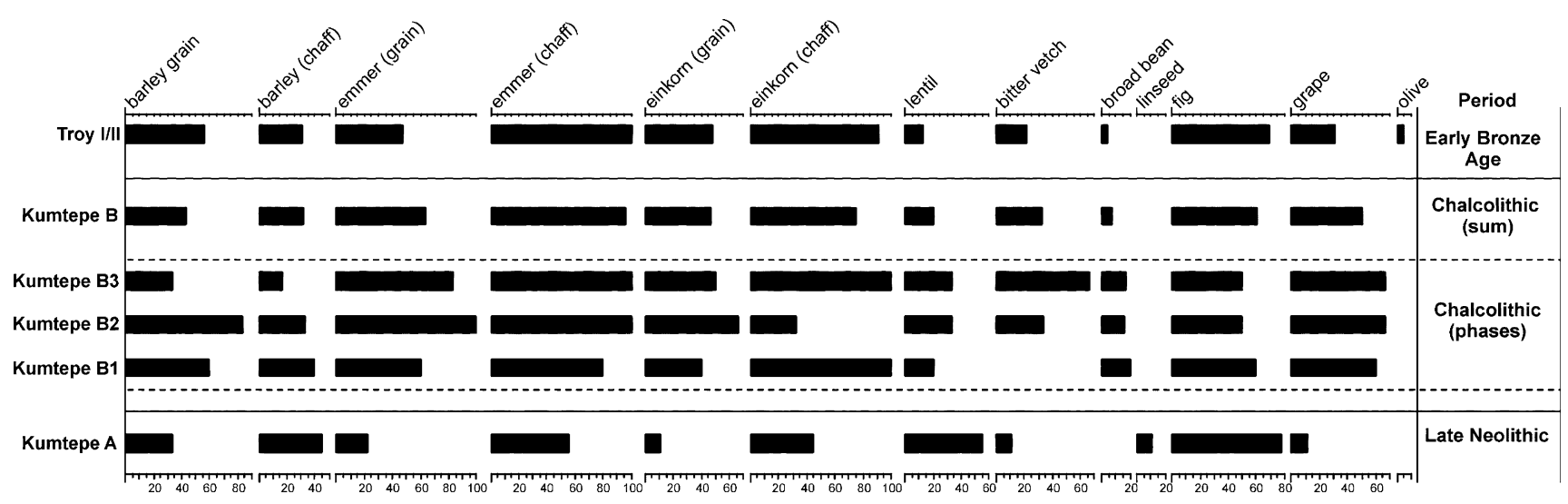

Fig. 4 Kumtepe and Early Bronze Age Troy food plant seed ubiquity (\%)

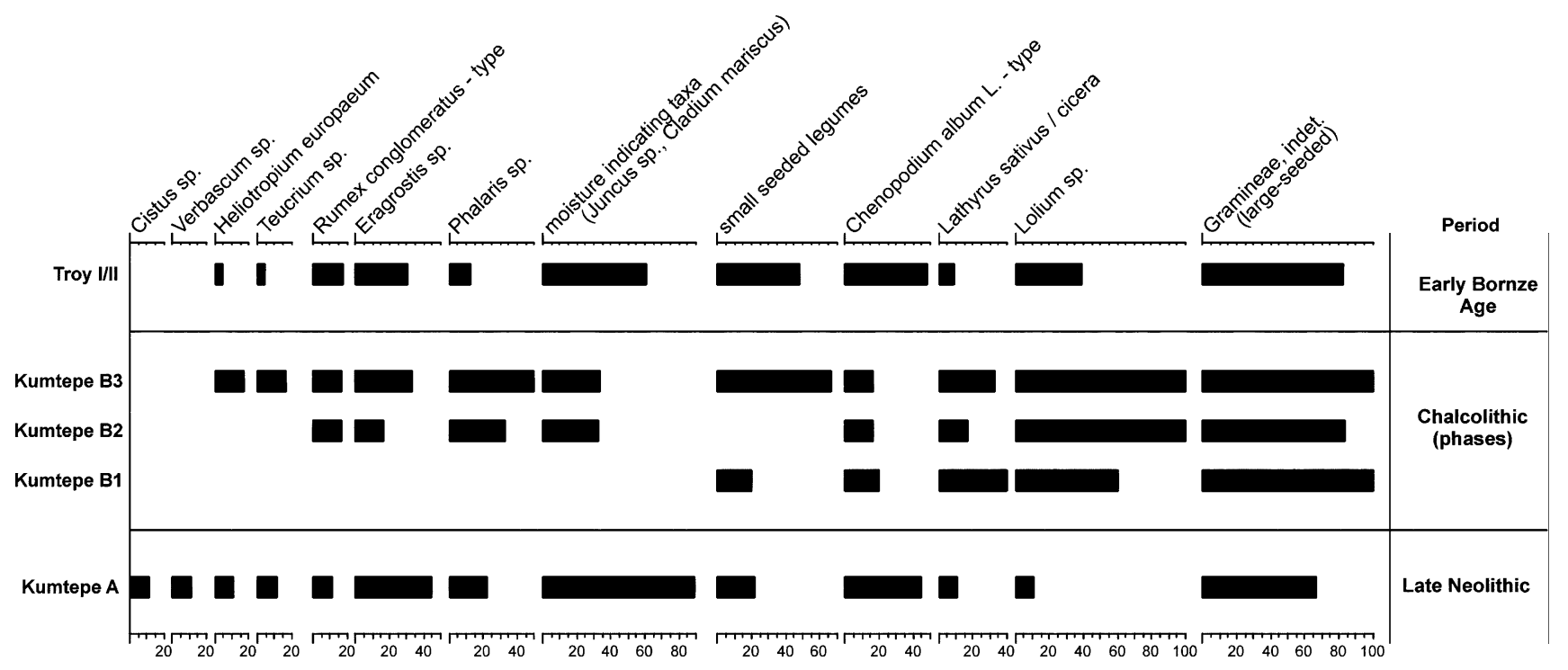

Fig. 5 Frequency of wild plant taxa (in \%) present throughout the whole Kumtepe sequence and at Early Bronze Age Troy

For both weedy (Chenopodium album-type, Lolium sp.) and freshwater types, the number of taxa, their amount and their ubiquity increase over time in the Kumtepe B deposits (Fig. 5). The ubiquity of typical cereal weed grasses increases from Kumtepe A to Kumtepe B3. Small-seeded grasses (Eragrostis sp., Phalaris sp.) are ubiquitous during Kumtepe A and disappear in Kumtepe B1, to reappear from Kumtepe B2 onwards, similarly to the taxa of moist habitats (Juncus sp., Cladium mariscus) (Fig. 5).

The charcoal assemblage of the Kumtepe B layers is analogous to Kumtepe A, dominated by deciduous oak species and pine. However, the proportion of pine-oak woodland is higher in Kumtepe B1, while shrub and maquis components are lower than in any other phase or period (Fig. 6). Generally, there is a decrease of oak and pine from Kumtepe B1 and Kumtepe B3. Evergreen oak is recorded in higher percentages during the Chalcolithic settlement period compared to the Late Neolithic, and increases throughout the Kumtepe B phases (Fig. 6, Table 2). There are six to seven taxa that belong to Mediterranean sclerophyllous forests and form maquistype vegetation (14\% of the charcoal remains) under human influence. Olive wood is present at Kumtepe B2, and there is also an increase in taxa of alluvial forests (Fig. 8, Chalcolithic).

Early Bronze Age (ca. 3000-2450 cal в.c.)

No significant changes in crop ubiquities are visible for Early Bronze Age Troy compared with Kumtepe B, except the occurrence of cultivated olive during the Early Bronze Age (Fig. 4). Amongst the seeds of wild plants the largeseeded grasses (probably cereal weeds) and various taxa from moist habitats [Chara sp. (oogonium), Cyperus 


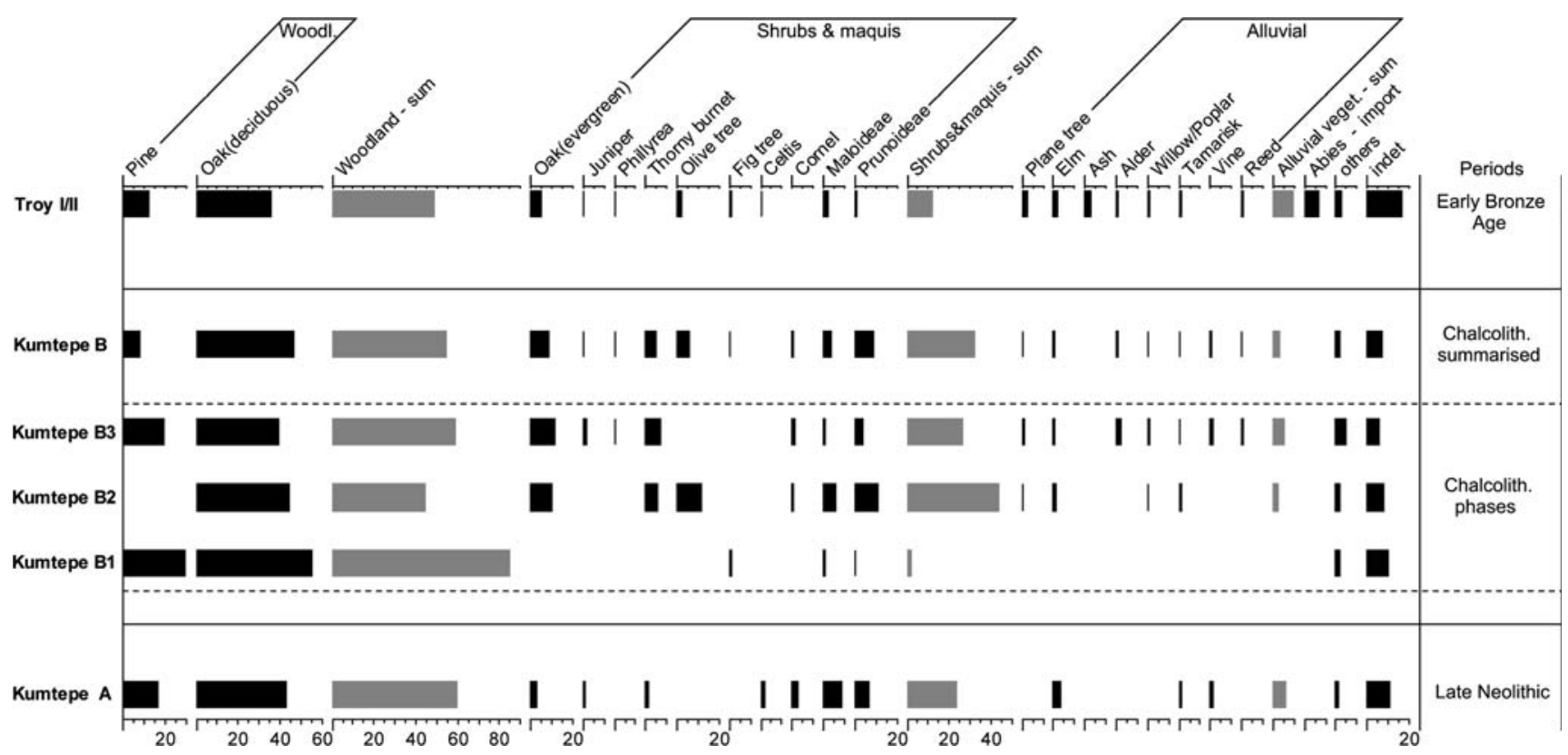

Fig. 6 Percentages of predominant wood taxa found during the different phases of Kumtepe A and B and Early Bronze Age Troy

longus L. type, Fimbristylis bisumbellata (Forssk.) Bubani, Scirpus maritimus L., Isoetes histrix Bory, Juncus sp., Typha cf. latifolia L., Salsola kali L., Aeluropus cf. littoralis (Gouan) Parl. and others] appear with the highest ubiquities. Many taxa of open vegetation are present, but they occur in relatively low frequencies.

The woodland proportion (oak and pine) in the Early Bronze Age charcoal assemblage is similar to that of Kumtepe B. However shrub and maquis components are reduced (particularly evergreen oak; thorny burnet is not represented at all) and taxa of alluvial vegetation are increased (Table 2, Fig. 8, Early Bronze Age).

The first record of probably imported wood occurs in Troy I/II. Fir (Abies sp.) was found in three samples. Today, Abies normandiana is located in the Ida Mountains, about $30 \mathrm{~km}$ from the site (Davis 1965-1988).

\section{Discussion and conclusion}

The results and conclusions are summarised in Fig. 9.

Taking subsistence patterns and their relevance to environmental reconstruction, a pronounced component of hunting and gathering during Kumtepe A becomes clear.

Kumtepe A layers are remarkable for an enormous amount of shells, such as Ostrea plicata (oyster) and $M y$ tilus edulis (mussel) (Sperling 1976). Fallow deer (Dama dama) are represented in particularly high proportions (Uerpmann 2003).

The most important domesticates are cattle, sheep and goats. Considering the weight of identified specimens
(WISP, according to Uerpmann 2003), cattle seems to dominate the complex. However, the far more usual measurement NISP (number of identified specimens) would reverse this result, indicating more than 50\% sheep and goats in the Kumtepe A layers.

In all, the faunal remains of Kumtepe A demonstrate that hunting (fallow deer) and gathering (mussels) were still a considerable aspect of the subsistence economy as compared to Kumtepe B or Early Bronze Age Troy. Taking the environmental preferences of fallow deer into account, the existence of more or less open, broad-leaved or mixed forests, probably dominated by oak species, might be expected for Kumtepe A, as is commonly argued by zooarchaeologists (cf. Benecke 2001).

Despite the smaller sample numbers from Late Neolithic contexts in comparison to the later periods, there is a strong indication that pulses, and in particular lentils, were intensively cultivated food plants during the Kumtepe A settlement period. This is also the case in other settlements, such as Late Neolithic Servia (Hubbard 1979) and, to a certain degree, at Ilıpınar (Cappers 2001). A general subsistence economy during the Late Neolithic obviously included a wide range of different crop plant species and an intense use of protein-rich pulses, as is also characteristic of archaeological sites in the neighbouring region of Thrace (Marinova 2002a, b; 2006). Pulses remained a very important food resource until the Early Bronze Age at somewhat isolated settlements, such as Yenibademli Höyük on Gökçeada Island (Oybak-Dönmez 2005). Why plant proteins seem to have played such a considerable role in the diet of some populations remains an unsolved 

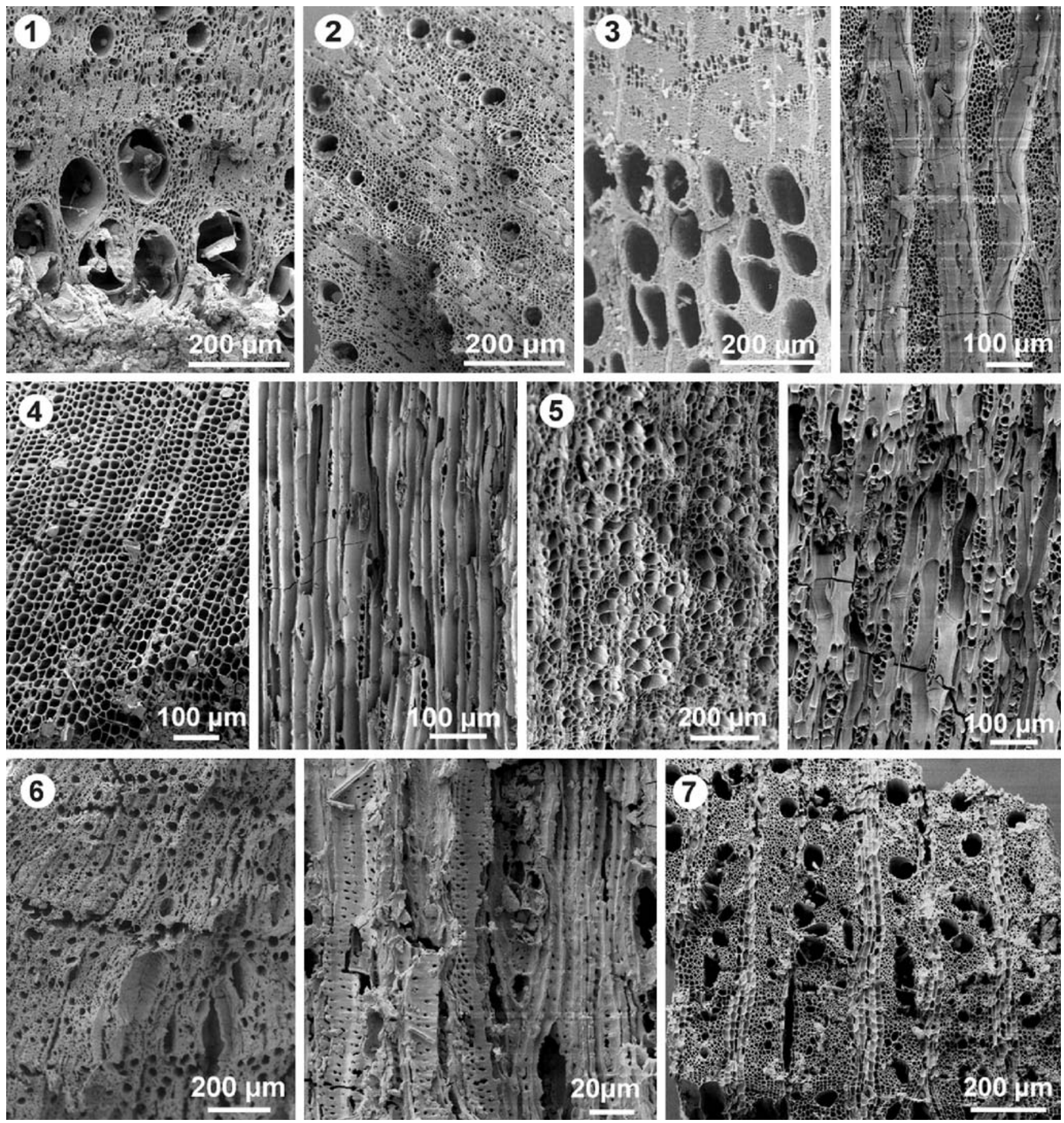

Fig. 7 Wood taxa: 1-Quercus sp. (deciduous); 2-Quercus sp. (evergreen); 3-Celtis sp.; 4-Juniperus sp.; 5-Olea europaea; 6-Sarcopoterium spinosum; 7-Tamarix $\mathrm{sp}$

question at the moment. Whether different living circumstances, influenced by more humid climatic conditions during this time, compared to later periods, could have had an effect on early crop plant preferences cannot be answered in this study. High proportions and ubiquities in fruits (fig tree) collected from the wild in the Late Neolithic
Troad, may support the argument of a strong gathering component correlating with the hunted faunal assemblage.

A marked reduction in fallow deer and the strong presence of pig amongst domesticates is characteristic of the Kumtepe B layers. This correlates to the fact that, after a hiatus of several hundred years, this settlement was 

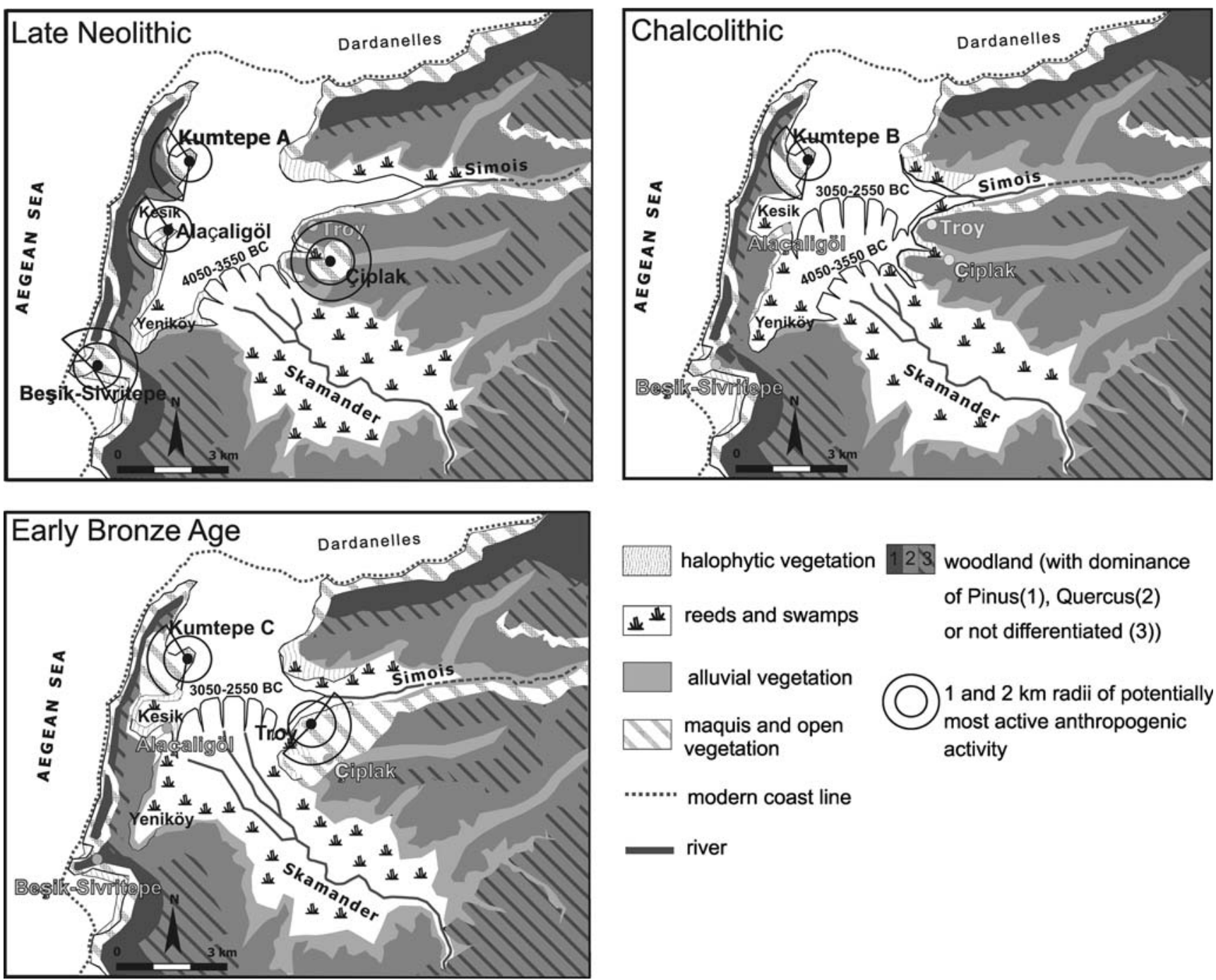

halophytic vegetation 123 woodland (with dominance

业 reeds and swamps

alluvial vegetation

maquis and open

vegetation

modern coast line

river

Fig. 8 Reconstruction of the vegetation during the Late Neolithic (Kumtepe A), the Chalcolithic period (Kumtepe B) and the Early Bronze Age (Troy I/II). Please note unhabited sites are indicated by white lettering

founded in a different environment by a new population with possibly different preferences in domesticates. Preferences for different domesticated animals seem to be environmentally (alluvial forests closer in the vicinity during the Chalcolithic as preferred locations of pig husbandry), and culturally determined (new population in Kumtepe B with significantly different proportions of domesticates). No drastic change between Kumtepe B and Early Bronze Age animal husbandry seems to have taken place. Pig was still an important component of the diet, although sheep and goats are even more dominant in the Early Bronze Age assemblages than before.

At Chalcolithic Kumtepe B, plant production patterns are dominated by cereals. Crop plant proportions at Early Bronze Age Troy are almost identical to those at Kumtepe $\mathrm{B}$, except for olive stones, which appear in the Troad for the first time during Troy IIa. However, olive wood is present from at least Kumtepe B2 onward, implying that the plant was not so wide-spread in the area until at least the middle Chalcolithic period (ca. $3300 \mathrm{cal}$ в.C.).

Emmer and einkorn are dominant in the Early Bronze Age contexts at Troy, followed by figs, grapes and pulses. The pulses occur at this time at somewhat lower values than during the Chalcolithic period, as is also the case in Early Bronze Age Kastanas (Kroll 1983). The weed spectrum during the Early Bronze Age is very similar to that of Kumtepe B, although the large-seeded cereal weeds (including Lolium spp.) occur at comparatively low frequencies. Taxa indicative of wet habitats are very frequent, correlating with the different geomorphological conditions at Early Bronze Age Troy, with the closer presence of the Scamander river delta, and is a record of different land use during this time (Figs. 1, 5). The radius of the catchment area seems to have been enlarged in the Chalcolithic period 


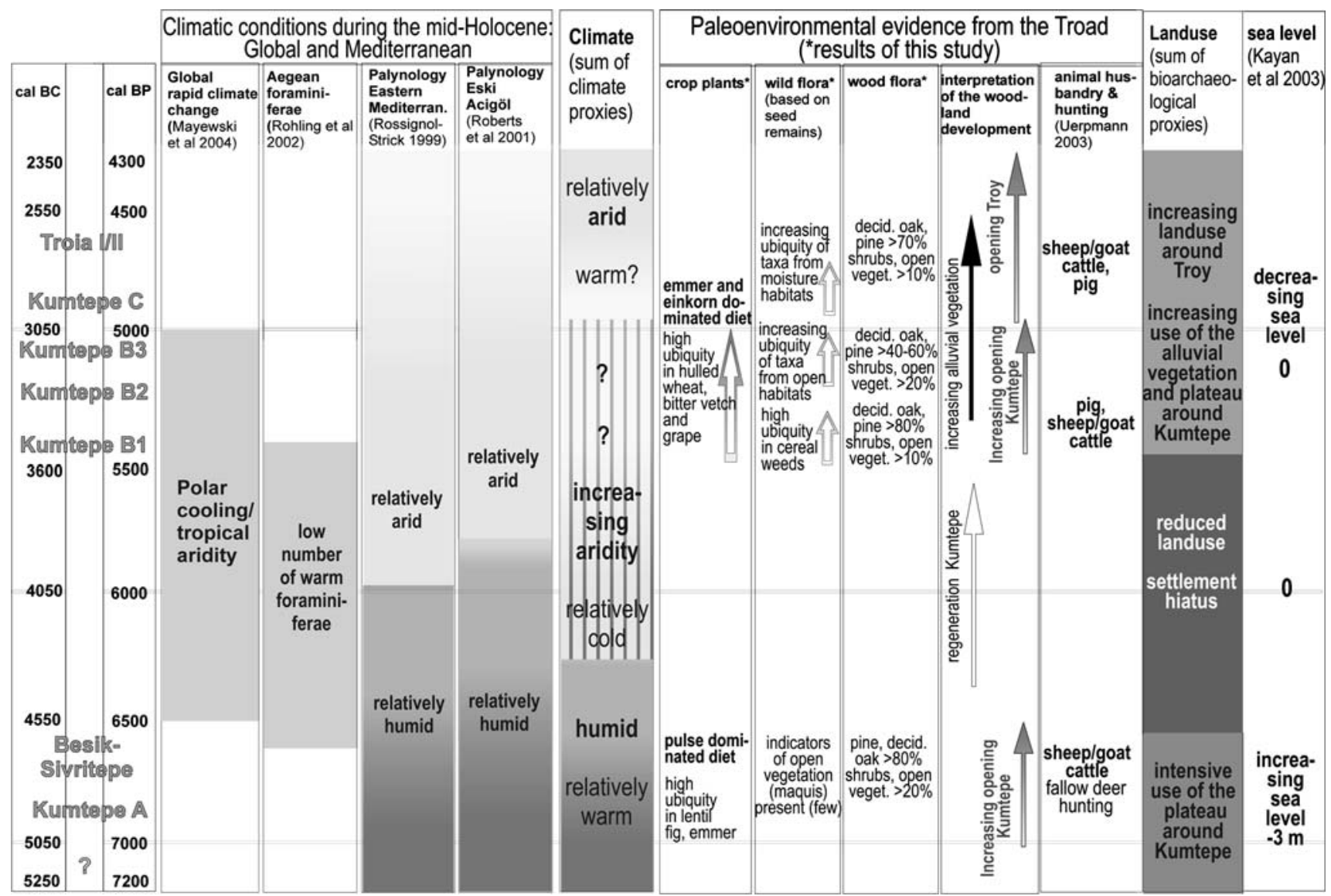

Fig. 9 Summary of palaeoclimatological, environmental and land use development

towards the river deltas in the east. Kumtepe was a coastal site during its whole settlement history. Visiting the river delta was obviously reasonable primarily during the Chalcolithic settlement period, when the Scamander delta was about $4 \mathrm{~km}$ away from Kumtepe, in contrast to the Late Neolithic when a walk of $10 \mathrm{~km}$ around the Yeniköy Bay was necessary to reach the river.

Although a relatively small number of charcoal samples were analysed from Kumtepe A layers, the results are important to our understanding of the environmental development of the area. They show the predominant use of oak and pine woodland in the Late Neolithic, very similar to that in the following periods. Deciduous oak was probably of multifarious economic importance from the beginnings of settlement in the Troad, considering its use as a fuel, building material, fodder (high nutritive content of the leaves and acorns for cattle, pigs etc.), and maybe for the extraction of tannin. The most widely distributed oak species in the area-vallonean oak (Quercus ithaburensis ssp. macrolepis)—usually forms park-like forests (Davis 1965-1988). Therefore some openness of the landscape is plausible during all periods, as supported by seeds of representative taxa of open habitats occurring already in
Kumtepe A (Sarcopoterium spinosum, Cistus sp., Verbascum sp.). The use of Celtis sp. during Kumtepe A also implies nearby open, rocky habitats in the surroundings.

The basic components (pine and deciduous oak) of the charcoal assemblage are particularly similar in Kumtepe B and Troy I/II, and although these principal components do not differ from the Late Neolithic assemblage of Kumtepe A, pine is recorded there in slightly higher fragment and weight percentages. This could be a sign of a somewhat different composition of oak and pine woodland in the Troad after the settlement hiatus (ca. 4600-3500 cal в.с.), implying a slightly reduced amount of pine in the Chalcolithic period. Bottema et al. (2001) also refer to the presence of increased numbers of pine trees during the Late Neolithic in the Yenişehir area. However further data would be necessary to conclude that the shift from more humid to more arid climatic conditions, mainly during the settlement hiatus at Kumtepe, influenced the composition of the regenerating oak-pine woodland in the Troad. The most common species in the area, Quercus ithaburensis ssp. macrolepis and Pinus brutia have both very wide ecological amplitudes and an almost identical vertical zonality. Any climatic argument for their different propor- 
tions during Kumtepe $\mathrm{A}$ is difficult to make. There may be other reasons, such as human preferences for the cutting of one or other species (e.g. Pinus species have a higher fuel value, cf. Théry-Parisot 2001), although these could not have been independent of climatic conditions. In contrast to pine, oak has the ability to regenerate under anthropogenic influence. In semi-humid Mediterranean environments oak starts to dominate over pine, but under fire regimes Pinus is more successful (Zavala et al. 2000).

In terms of identifying human impact in the charcoal composition, the presence of maquis indicators such as Sarcopoterium spinosum and evergreen oak during the Late Neolithic Kumtepe A settlement is remarkable. This impact increases during the Kumtepe B settlement, although the composition of Kumtepe B1 suggests that an almost complete regeneration of woodland must have taken place at least toward the end of the settlement hiatus (Figs. 5, 8).

There is continuing vigorous debate as to the extent to which sclerophyllous communities exist as a response to climatic change during the Holocene or to human influence (cf. Allen 2003; Quézel 1999). Both hypotheses are justified and well supported by arguments. Many of the elements of the maquis vegetation that are identifiable in the Neolithic and Chalcolithic material from Kumtepe could alternatively grow in pine and oak forests. After degradation, it is almost impossible to distinguish from which initial community the maquis originates.

At Early Bronze Age Troy the shrub and maquis components are slightly reduced, implying a locally lesser degree of degradation of the vegetation due to a longer settlement history at Kumtepe and the availability of wood resources far inland on the high plateau near Early Bronze Age Troy.

We also want to emphasise that although indicators of open vegetation are present at Kumtepe A, there are no steppe elements that would indicate arid environments. Considering the palaeoclimatological reconstructions (Fig. 9) the precipitation in the area was probably not under the critical $400-350 \mathrm{~mm}$ per year that would allow Pinus to dominate clearly over oak in the Mediterranean climate (Zavala et al. 2000). The bioclimatic niche of Quercus ithaburensis ssp. macrolepis, which is characterised by a semi-arid to humid climate and a maximal length of 5 months of dry season (Dufour-Dror and Ertas 2004) suggests that the study area during the mid-Holocene continuously offered adequate conditions for its growth.

On the basis of our results and the available data on the climate and vegetation history in that area, we suppose that during the Late Neolithic, sclerophyllous taxa, together with a relatively high component of non-weedy grasses, were only distributed on naturally open locations, such as rocky places, stony slopes etc.
The overall pattern suggests a forest and oak woodland dominated landscape during the mid-Holocene. A diverse flora of moisture indicating seed plants supports the argumentation of a well-balanced water supply, at least until about 4600 cal B.C.

Although there are no direct data from the settlement hiatus other than the proposed local open vegetation as indicated in the fossil soil, it seems likely that the environmental conditions were no longer ideal due to an increasingly arid climate. This may be supported by Bond Event 4 (Bond et al. 1997) occurring within the hiatus sequence between 4600 and 3500 cal B.C. Modelled precipitation for the Troad shows lowest precipitation during the settlement hiatus at Kumtepe (ca. 4600-3500 cal в.c.) as compared with both settlement periods. Following the arid period during the settlement hiatus, precipitation during Kumtepe B increases, but does not reach the level calculated for Neolithic Kumtepe A.

In discussing the oak woodland degradation, Kumtepe B2, starting around 3300 cal B.C. seems to show clear evidence of this with a decrease in deciduous oak and an increase in evergreen oak. This degradation was probably reinforced by a more arid climate than that of the Kumtepe A environment. However, our data are not sufficient to claim that this date is other than a terminus post quem.

The question of whether changes in the composition of the vegetation in the mid-Holocene Troad are either manmade or natural is redundant, as processes are never without reciprocity and are strongly subordinated to variable and mostly unknown population densities. In the Troad phases, probable intense human impact alternates with that of a primarily natural character (Fig. 9).

The first settlers of the area at the beginning of Kumtepe A (around 5000 cal B.c.) would have found the original vegetation composition, with high proportions of oak and pine woodland. The woodland may have been somewhat open. However it remains difficult to decide whether indicators of open vegetation units, such as Sarcopoterium spinosum, Cistus sp. or Verbascum sp., were already present as part of the natural vegetation in the area on the arrival of the first settlers, although this is the most likely explanation. The latter two indicators do not occur again in the Troad until the Middle Bronze Age.

Nevertheless we do not exactly know what happened during the period of the settlement hiatus (4600-3500 cal B.c.) aside from a cooling event in the middle and the formation of a soil under open vegetation. However it is obvious from the composition of the flora at the resettlement of Kumtepe starting around 3500 cal B.C. that the vegetation recovered from the earlier impact. Components of the maquis and shrub units almost disappeared, while pine and oak must have extended their range again until Kumtepe B1. In the course of the Kumtepe B settlement 
(until ca. $3000 \mathrm{cal}$ B.c.) there is clear evidence from increasing proportions of characteristic plants of the maquis and shrub vegetation (see also Fig. 6) for a man-made opening of the vegetation in the surroundings of the sites. However human impact at Troy further to the east seems to have been insignificant before the beginning of the Early Bronze Age.

Acknowledgments We would like to thank the late Prof. M.O. Korfmann, head of the Troy and Kumtepe excavations, for permission to work with Kumtepe plant remains. P. Jablonka and P. Zidarov provided additional samples from Kumtepe A. Profs. N.J. Conard and H.-P. Uerpmann supported our project by placing the laboratory equipment at Tübingen University at our disposal. Special thanks go to Utta Gabriel for fruitful discussions on the archaeology of Kumtepe and to Mark Nesbitt for comments on an earlier version of the manuscript. We are also grateful for perceptive comments from two anonymous reviewers. For financial support, we thank the WilhelmSchuler-Stiftung Tübingen and the German Academic Exchange Service (DAAD).

\section{References}

Alex M, Burry M (1982) Temperatur- und Niederschlagswerte von Stationen des Vorderen Orients. Bd. 4: Türkei. Institut für Geographie, Universität Tübingen

Allen HD (2003) Response of past and present Mediterranean ecosystems to environmental change. Prog Phys Geogr 27:359377

Asouti E, Austin P (2005) Reconstructing woodland vegetation and its exploitation by past societies, based on the analysis and interpretation of archaeological wood charcoal macro-remains. Environ Archaeol 10:1-18

Benecke N (2001) Die Tierwelt Thrakiens im Mittelholozän (ca. 6000-2000 v. Chr.) — anthropogene und natürliche Komponenten. In: May E, Benecke N (eds) Beiträge zur Archäozoologie und Prähistorischen Anthropologie, Band III. Wais \& Partner, Stuttgart, pp 29-38

Blegen CW (1950) Troy I-IV. In: Excavations conducted by the University of Cincinnati 1932-1938, Princeton

Bohn U, Gollub G, Hettwer C, Neuheuslová Z, Schlüter H, Weber H (2003) Map of the natural vegetation of Europe. Scale 1:2500000. Landwirtschaftsverlag, Bonn

Bond G, Showers W, Cheseby M, Lotti R, Almasi P, deMenocal P, Priore P, Cullen H, Hajdas I, Bonani G (1997) A pervasive millennial-scale cycle in North Atlantic Holocene and glacial climates. Science 278:1257-1266

Bottema S, van Zeist W (1980) Palynological evidence for the climatic history of the Near East 50000-6000 BP. Colloq Int C.N.R.S. 598:111-132

Bottema S, Woldring H, Kayan I (2001) The late quaternary vegetation of Western Turkey. In: Roodenberg J, Thissen L (eds) The Ilipinar excavations II. Nederland Intituut voor Nabije Oosten, Leiden, pp 327-356

Browicz K (1994) Chorology of trees and shrubs in south-west Asia and adjacent regions, vol 10. Polish Academy of Sciences, Institute of Dendrology, Poznan

Bryson RA (1988) Late quaternary volcanic modulation of Milankovitch climate forcing. Theoret Appl Climatol 39:115

Bryson RA (1992) A macrophysical model of the Holocene intertropical convergence and jetstream positions and rainfall for the Saharan region. Meteorol Atmos Phys 47:247-258
Bryson RA (2005) Archaeoclimatology. In: Oliver JE (ed) The encyclopedia of world climatology. Springer, Dordrecht, pp 5863

Bryson RA, Bryson RU (1997) High resolution simulations of regional Holocene climate: North Africa and the Near East. In: Dalfes HN, Kukla G, Weiss H (eds) Third millennium BC climate change and Old World collapse. NATO ASI series, vol I 49. Springer, Heidelberg, pp 565-594

Bryson RU, Bryson RA (1998) Application of a global volcanicity time-series on high-resolution paleoclimatic modeling of the eastern Mediterranean. In: Issar AB (ed) Water, environment and society in times of climatic change. Water science and technology library, vol 31. Kluwer, Dordrecht, pp 1-19

Cappers RTJ (2001) Plant remains from Phase VB. A preliminary report. In: Roodenberg J, Thissen L (eds) The Ilipinar excavations 2. Nederland Historical-Archaeological Institute, Leiden, pp 236-237

Davis PH (ed) (1965-1988) Flora of Turkey and the East Aegean Islands, vol 10. Edinburgh University Press, Edinburgh

Dörpfeld W (1902) Troja und Ilion. Ergebnisse der Ausgrabungen in den vorhistorischen und historischen Schichten von Ilion-1894, Athens

Dufour-Dror J-M, Ertas A (2004) Bioclimatic perspectives in the distribution of Quercus ithaburensis Decne. Subspecies in Turkey and in the Levant. J Biogeogr 31:461-474

Gabriel U (2000) Mitteilung zum Stand der Neolithikumsforschung in der Umgebung von Troia (Kumtepe 1993-1995; Besik-Sivritepe 1983-1984, 1987, 1998-1999). Stud Troica 10:233-238

Gabriel U, Aslan R, Blum S (2004) Alacaligöl. Eine neuentdeckte Siedlung des 5. Jahrtausends v.Chr. in der Troas. Stud Troica 14:121-133

Hansen JM (1991) The palaeoethnobotany of Franchthi Cave. In: Excavations at Franchthi Cave, Greece 7. Indiana University Press, Bloomington

Hansen JM, Renfrew JM (1978) Palaeolithic-Neolithic seed remains at Franchthi cave, Greece. Nature 271:349-352

Heinz C, Thiébault S (1998) Characterization and palaeoecological significance of archaeological charcoal assemblages during Late and Post-Glacial phases in Southern France. Q Res 50:5668

Hopf M (1961) Pflanzenfunde aus Lerna/Argolis. Züchter 31:239-247

Hubbard RNL (1979) Ancient Agriculture and ecology at Servia. In: Ridley C, Wardle KA (eds) Rescue excavations at Servia 19711973: a preliminary report. Annual of the British School at Athens, vol 74, pp 226-228

Kayan I (1995) The Troia Bay and supposed harbour sites in the Bronze Age. Stud Troica 5:211-235

Kayan I (1999) Holocene stratigraphy and geomorphological evolution of the Aegean coastal plains of Anatolia. Q Sci Rev 18:541548

Kayan I, Öner E, Uncu L, Hocaoglu B, Vardar S (2003) Geoarchaeological interpretation of the Troian Bay. In: Wagner G, Pernicka E, Uerpmann H-P (eds) Troia and the Troad. Scientific approaches. Springer Heidelberg, pp 379-402

Korfmann M, Kromer B (1993) Demircihüyük, Besik-Tepe, Troia-Eine Zwischenbilanz zur Chronologie dreier Orte in Westanatolien. Stud Troica 3:135-172

Korfmann M (ed) (1991-2006) Various articles in Studia Troica

Korfmann M, Girgin Ç, Morçöl Ç, Kiliç S (1995) Kumtepe 1993. Bericht über die Rettungsgrabung. Stud Troica 5:237-289

Korfmann M, Gabriel U, Bertram J, Karul N (1996) Bericht zu den Rettungsgrabungen am Kumtepe in den Jahren 1994 und 1995. Troia Projekt

Kraft JC, Kayan I, Erol O (1982) Geology and paleogeographic reconstructions of the vicinity of Troy. In: Rapp GR, Gifford JA (eds) Troy-the archaeological geology. Cincinnati, pp 11-41 
Kroll H (1983) Kastanas. Die Pflanzenfunde. Prähistorische Archäologie in Südosteuropa 2. Volker Spiess, Berlin

Marinova E (2002a) Ergebnisse archäobotanischer Untersuchungen aus dem Neolithikum und Chalkolithikum in Südwestbulgarien. Archaeol Bulg VI(3):1-11

Marinova E (2002b) Mittel- und spätneolithische botanische Funde. In: Hiller S, Nikolov V (eds) Karanovo II. Die Ausgrabungen in O 19, vol 2, Salzburg, Sofia, pp 171-179

Marinova E (2006) Vergleichende paläoethnobotanische Untersuchung zur Vegetationsgeschichte und zur Entwicklung der prähistorischen Landnutzung in Bulgarien. Diss Bot 401. Gebr. Borntraeger, Stuttgart

Mayewski P, Rohling E, Stager C, Karlen W, Maascha K, Meeker D, Meyerson E, Gasse F, Kreveld SV, Holmgren K, Lee-Thorp J, Rosqvist G, Rack F, Staubwasser M, Schneider R, Steig E (2004) Holocene climate variability. Q Res 62:243-255

Nesbitt M (1996) Chalcolithic crops from Kuruçay Höyük, an interim report. In: Duru R (ed) Kuruçay Höyük II. Results of the excavations 1978-1988. The Late Chalcolithic and Early Bronze settlements. Türk Tarih Kurumu Basimevi, Ankara, pp 134-144

Oybak-Dönmez E (2005) Early Bronze Age crop plants from Yenibademli Höyük (Gökçeada), Western Turkey. Environ Archaeol 10:39-50

Pustovoytov KE (1999) Die spätholozäne Bodenerosion in der Umgebung von Troia im Spiegel der Bodendecke. Stud Troica 9:354-366

Quézel P (1999) Les grandes structures de végétation en région méditerranéenne. facteurs déterminants dans leur mise en place postglaciaire. Geobios 32:19-32

Riehl S (1999) Bronze Age environment and economy in the Troad. The archaeobotany of Kumtepe and Troy. BioArchaeologica 2. Mo Vince Verlag, Tübingen

Roberts N, Reed J, Leng MJ, Kuzucuoglu C, Fontugne M, Bertaux J, Woldring H, Bottema S, Black S, Hunt E (2001) The tempo of Holocene climatic change in the Eastern Mediterranean region. New high-resolution crater-lake sediment data from central Turkey. Holocene 11:721-736

Roberts N, Stevenson T, Davis B, Cheddadi R, Brewster S, Rosen A (2004) Holocene climate, environment and cultural change in the Circum-Mediterranean region. In: Battarbee RW (ed) Past climate variability through Europe and Africa. Springer, Dordrecht, pp 343-362
Rohling E, Mayewski P, Hayes A, Abu-Zied RH, Casford JSL (2002) Holocene atmosphere-ocean interactions. Records from Greenland and the Aegean Sea. Clim Dyn 18:573-592

Rossignol-Strick M (1999) The Holocene climatic optimum and pollen records of sapropel 1 in the eastern Mediterranean, 90006000 BP. Q Sci Rev 18:515-530

Schliemann H (1881) Stadt und Land der Trojaner. Forschungen und Entdeckungen in der Troas und besonders auf der Baustelle von Troja, Leipzig

Schliemann H (1884) Troia. Ergebnisse meiner neuesten Ausgrabungen auf der Baustelle von Troia, in den Heldengräbern, Bunarbaschi und anderen Orten der Troas im Jahre 1882, Leipzig

Schweingruber FH (1990) Anatomie europäischer Hölzer. Ein Atlas zur Bestimmung europäischer Baum-, Strauch- und Zwergstrauchhölzer. Haupt, Bern Stuttgart

Sperling JW (1976) Kum Tepe in the Troad. Trial excavation 1934. Hesperia 45:305-364

Théry-Parisot I (2001) Économie des combustibles au Paléolithique. Dossier de documentation archéologique 20. CNRS éditions, Paris

Uerpmann H-P (2003) Environmental aspects of economic changes in Troia. In: Wagner G, Pernicka E, Uerpmann H-P (eds) Troia and the Troad Scientific approaches. Springer, Heidelberg, pp 251263

van Zeist W, Bottema S (1991) Late quaternary vegetation of the near East. Beihefte zum Tübinger Atlas des Vorderen Orients A 18. Dr. Ludwig Reichert Verlag, Wiesbaden

Virchow R (1879) Beiträge zur Landeskunde der Troas. Abhandlungen der Königlichen Akademie der Wissenschaften zu Berlin. Physikalische Klasse, Abhandl.III., Berlin

Weninger B, Alram-Stern E, Bauer E-M, Clare L, Danzeglocke U, Jöris O, Kubatzki C, Rollefson GO, Todorova H (2005) Die Neolithisierung von Südosteuropa als Folge des abrupten Klimawandels um 8200 cal BP. In: Gronenborn D (ed) Klimaveränderung und Kulturwandel in neolithischen Gesellschaften Mitteleuropas 6700-22 v.Chr. RGZM-Tagungen, vol 1, pp $75-117$

Zavala M, Espelta J, Retana J (2000) Constraints and trade-offs in Mediterranean plant communites: the case of Holm Oak-Aleppo Pine forests. Bot Rev 66:119-149

Zohary M (1973) Geobotanical foundations of the Middle East. Fischer, Stuttgart 